\title{
DISCURSO RELIGIOSO EM OLHAI OS LÍRIOS DO CAMPO
}

\author{
Daniela Borja Bessa*
}

RESUMO :

\begin{abstract}
Este artigo procura demonstrar a importância do discurso religioso, principalmente do texto bíblico do Sermão da Montanha, na constituição dos personagens, assim como da relação existente entre aceitação de Deus, descoberta de um sentido para a vida e luta contra as injustiças sociais.

PALAVRAS-CHAVE: romance brasileiro, romance modernista, literatura e religião, Sermão da Montanha, Érico Veríssimo.
\end{abstract}

\begin{abstract}
"Antigamente só pensava em mim mesmo. Vivia como cego. Foi 0lívia quem me fez enxergar claro. Ela me fez ver que a felicidade não é o sucesso, o conforto. Uma simples frase me deixou pensando: Considerai os lírios do campo. Eles não semeiam, nem tecem e no entanto nem Salomão em toda a sua glória se cobriu como um deles." (Veríssimo, 1976: 281)
\end{abstract}

0 olhar é o sentido privilegiado no romance Olhai os lírios do campo. As relações entre os personagens e as mudanças que eles atravessam se estabelecem principalmente através do olhar. 01hares presos ao passado, olhares que vislumbram o futuro e com ele sonham, olhares opacos, passivos ou vivos, inquietantes, apresentamse na cena romanesca. É o deslocamento do olhar, de si mesmo para o outro, mediado pelo discurso religioso a temática principal da obra. Esse romance também possibilita um novo olhar dos críticos e do público sobre a obra de Érico Veríssimo. Escrito em $3^{a}$ pessoa, ele se centra no personagem Eugênio e em seus conflitos familiares, sociais e religiosos.

0 título do romance antecipa o principal conflito de que ele trata: o conflito religioso. Esse conflito pode ser analisado à luz do Sermão da Montanha. Proferido por Jesus para seus discípulos, esse sermão sistematiza seus ensinamentos. Dentre os vários aspectos abordados pelo Sermão, um deles foi tomado como referência para a composição do texto romanesco: a inquietude que aflige os seres humanos * Mestre em Letras: Estudos Literários (Área de concentração: Literatura Brasileira), 2000. 


\section{EM TESE}

Belo Horizonte, v. 5, p. I-305, dez. 2002

diante das imposições concretas da vida material. 0 texto retirado do Sermão é o seguinte:

E por que andais ansiosos quanto ao vestuário? Considerai como crescem os lírios do campo: eles não trabalham, nem fiam. Eu, contudo, vos afirmo que nem Salomão, em toda a sua glória, se vestiu como qualquer deles. Ora, se Deus veste assim a erva do campo, que hoje existe e amanhã é lançada no forno, quanto mais a vós outros, homens de pequena fé? (Mateus 6.28-30)

Pode-se dizer que o tema do romance Olhai os lírios do campo gira em torno de tal questionamento: a necessidade humana de adquirir projeção social e reconhecimento pelos bens que possui, em detrimento da necessidade de se relacionar profunda e verdadeiramente seja com as pessoas, seja com Deus. 0 personagem principal do romance, Eugênio Fontes, experimenta uma grande crise ao se ver forçado a optar por um dos dois extremos: o materialismo ou a fé.

Por um 1ado, na vertente materialista estão a busca por ascensão e reconhecimento sociais e, na vertente religiosa, por outro lado, estão a busca por alcançar a paz interior e descobrir um sentido para a vida, ambos esses aspectos associados e dependentes de seu relacionamento com Deus. Fé e materialismo são os temas que perpassam e se contrastam ao longo de toda a obra. Eugênio transita de um pólo ao outro.

0 romance obedece a uma estrutura dupla não apenas na divisão em temas, mas na sua própria organização. Ele é dividido em duas partes com características bastante diferenciadas, particularmente no que se refere à forma de composição.

Na primeira parte do romance, formada pelos doze capitulos iniciais, o narrador constrói a imagem de Eugênio, remetendo os leitores à infância e juventude desse personagem de tal maneira que se tem a impressão de um relato memorialístico. Ao longo desses capítulos várias situações que se disseminam no romance, funcionam como "indices" ou elementos que remetem para significados mais amplos. Estamos empregando a palavra "índice" na acepção em que Roland Barthes a utilizou em seu ensaio: "Análise Estrutural da Narrativa". Tais significados (os dos índices) se referem ao caráter do personagem, marcado pela ambição, pelo desprezo aos que são economicamente inferiores e pelas relações sociais e afetivas superficiais, baseadas em interesses econômicos. 
Confrontado com seus próprios valores, adquiridos na luta por uma posição estável e socialmente respeitável, o personagem experimenta uma crise e é dela que trata a segunda parte do livro, formada pelos capitulos treze a vinte e quatro. Essa segunda parte aborda os questionamentos enfrentados pelo personagem para encontrar uma saída da situação desconfortável em que se vira imerso.

Em ambas as partes, a dimensão temporal assume, na estrutura do romance, um papel muito importante. Na primeira, construída, segundo os críticos João Gaspar Simões e Temístocles Linhares, com genialidade e virtuosismo de composição, as retrospecções dominam a narrativa, estando presentes na maior parte dos capítulos. Ao final de cada um deles, entretanto, a narrativa retorna ao tempo presente. Presente e pretérito coexistem ao longo dessa etapa, com funções diferentes. 0 tempo presente não é o tempo da narração. Ele surge ao final de cada capítulo, retomando a narrativa do primeiro deles, também feita toda no presente, fornecendo-1he uma linha seqüencial e atualizando-a. A distinção entre os dois tempos não é apenas temática, mas também tipográfica. A narração ocorrida no passado se apresenta em caracteres redondos e aquelas que retomam o capítulo inicial do romance, no tempo presente, são grafadas em itálico.

$\mathrm{Na}$ segunda parte do romance, por outro lado, a dimensão temporal exerce uma função distinta daquela que exercera na primeira. Seu caráter não é retrospectivo, e, sim, prospectivo, apontando para os planos, projetos e decisões do personagem principal.

A busca por riquezas, como reação a uma vida de miséria e desconsideração, é a principal característica de Eugênio. Através dos ideais desse personagem são criticados os valores que regem a vida em sociedade, o sistema capitalista de produção de bens e a reificação das pessoas.

Olhai os lírios do campo, pelas características apontadas, pode ser comparado com dois outros romances. Um deles é Contraponto. Traduzido por Érico Veríssimo em 1933, esse romance teve repercussões na produção literária dele. 0 romance de Huxley guarda semelhanças com Olhai os lírios do campo porque aborda a relação entre os seres humanos, tendo como paradigma o poder do dinheiro. É ele que determina todos os relacionamentos e controla todas as decisões. Outro ponto em 


\section{EM TESE}

Belo Horizonte, v. 5, p. I-305, dez. 2002

comum entre essas obras que pode ser assinalado é a inserção, em ambas, do mesmo trecho bíblico do Sermão da Montanha, com o mesmo sentido de crítica à ganância e ansiedade pela aquisição de bens em detrimento da confiança na providência divina.

0 outro romance que pode ser posto em relação com Olhai os lírios do campo é a obra de Goethe Os anos de aprendizagem de Willhelm Meister. Ambas essas obras podem ser classificadas como romances de formação, como romances que mostram que o herói se modifica com o tempo. Em Willhelm Meister é mostrada a evolução do personagem principal de uma situação de total insegurança para a de autoconfiança. Ele busca equilibrar ação e contemplação, vontade de intervir no mundo e condições para fazê-10. Essa evolução só foi possível quando Willhelm Meister conseguiu a integração de sua interioridade com a realidade objetiva. Eugênio, no romance de Érico Veríssimo, também precisará vivenciar algo semelhante, uma vez que ele se recusa, inicialmente, a enxergar a realidade de forma objetiva e a refletir sobre seu mundo interior.

Pela sua dificuldade em relacionar-se com a realidade exterior, Eugênio pode ser classificado como um herói problemático. Segundo Lucien Goldmann essa caracterização se aplica àquele personagem "cuja existência e valores o situam perante problemas insolúveis, dos quais ele não é capaz de adquirir uma consciência clara e rigorosa." (Goldmann, 1967: 116) Ele é prisioneiro de seu contexto de vida, das escolhas que fizera, e principalmente das pressões sociais.

Ao ser confrontado com ideais não alcançados e experimentar conflitos para os quais não consegue encontrar solução, esse personagem entra em uma crise. Essa crise provoca culpa em sua consciência e o inquieta. Ele se confronta, então, com sua postura diante das situações que vivenciara e evolui da posição de vítima para a de responsável por suas escolhas. Vários fatores haviam contribuído para conduzi-10 à situação de vítima do passado, como as privações que sofrera e os discursos a que fora submetido.

Eugênio é um personagem marcado pelas lembranças de privações econômicas e afetivas. Ele se envergonhava da subserviência paterna, traço que também ele herdara e do conformismo materno, associado à noção de destino e à idéia de Deus. 0 confronto de Eugênio com Deus, de alguma forma, exemplifica seu confronto com os 
valores herdados dos pais e de sua cultura. Questionar a existência de Deus, para ele, é o mesmo que questionar a desigualdade social, a resignação materna, a reificação das relações humanas.

Questionar Deus é também questionar os dogmas religiosos e a religião formal, como também a perspectiva sob a qual Ele é visto. A injustiça social é encarada a partir da concepção de Deus como um ser vingativo. Essa é a imagem que acompanha a infância de Eugênio. Ele se depara, constantemente, com um Deus que deixou as pessoas à sua própria sorte e que se interessa apenas em castigá-los. Como reação às concepções recebidas de um Deus distante e incomunicável, Eugênio opta pelo ateísmo.

0 ateísmo, entretanto, não permanece como marca desse personagem, pois a fé, desde a infância, The aparece como uma alternativa para o medo da morte e para o confronto com o desconhecido. A saída do ateísmo só se faz pela alteração da compreensão de Deus e de Seus atributos. Em lugar do castigo e do zelo de Deus sobressaem Seu amor e Seu cuidado. Tais características do Ser divino the são reveladas por uma ex-namorada, 0lívia.

01 ivia the apresenta a face amorosa e cuidadosa de Deus e o confronta com um novo discurso religioso, baseado na participação na coletividade humana, na solidariedade, no encontro com o próximo. Como afirma Malory Pompermayer, "é através do 'tu' dos irmãos que nos aproximamos do 'tu' divino. Porque ser-se cristão significa abandonar uma existência egoísta, a vida por si mesma, para viver em função dos outros." (Pompermayer, 1969: 49)

Após experimentar uma crise de valores, Eugênio é confrontado consigo mesmo. Esse confronto encontra expressão literária por meio de um concerto de vozes. É dele que trata a segunda parte do romance. São as vozes dos outros personagens que vão possibilitar a desestabilização e a reorganização do personagem principal. Tais discursos postos em confronto contribuem para que Eugênio transforme sua situação e saia da crise em que se encontra.

0 discurso de 01 ivia, que se manifesta nas cartas deixadas por ela e que são lidas após sua morte, traz à tona o papel da religião e permite o confronto de Eugênio com a fé. Os diálogos entre Eugênio e 011 via, em que ocorre a contraposição de dois discursos diferentes, estão impregnados de um caráter messiânico, salvacionista. 


\section{EM TESE}

Belo Horizonte, v. 5, p. I-305, dez. 2002

Nas cartas que deixara, 0livia aborda valores morais e religiosos, enfatizando a importância da solidariedade, como também a necessidade do discurso religioso transformar-se em prática.

0 Sermão da Montanha, citado na última carta, assume proeminência para que as mudanças ocorram. 0 trecho retirado dele traz a mensagem de que a perspectiva humana individualista, gananciosa e egocêntrica de vida deve ceder lugar à busca por relacionamentos com as outras pessoas. Através das palavras de Cristo, Eugênio é alertado para os valores que movem o mundo, como também para a ansiedade decorrente da aquisição dos bens terrenos. Por outro lado, ele também é apresentado a valores novos que poderiam reger a vida terrena, ligados ao amor, à solidariedade, à confiança em Deus.

Outro discursos que, confrontando o de Eugênio, contribuem para 0 abandono da postura de autocomiseração que o caracterizava são o do Dr. Seixas, que reconduz Eugênio ao mundo da pobreza, do qual ele vivia fugindo e defende o valor da solidariedade como uma tentativa de se minimizar a dor do outro, e o de Filipe Lobo, que suscitam-1he questionamentos sobre o perigo de se deixar levar pelo valor temporal das riquezas e pelas aparências.

Se, na primeira parte do romance, Eugênio é apresentado como um herói problemático, na segunda o narrador mostra como ele superou essa condição, reconciliando-se consigo mesmo, com a sociedade e com a fé, embora não abrace uma crença religiosa.

Olhai os lírios do campo pode ser considerado um romance históricosocial, pois além da análise das relações sociais, empreende uma releitura da história, possibilita à história ser analisada criticamente. Como outros romances da década de 30 , Olhai os lírios do campo denuncia os desacordos da vida social de seu tempo, ainda que não o faça de maneira incisiva ou panfletária.

No romance há a defesa dos ideais humanistas e também está exposto o temor de que a liberdade do homem seja ameaçada pelos regimes totalitários. Escrito nos tempos do fascismo, o romance constrói uma crítica veemente a esse regime. A defesa veemente da liberdade de expressão e a crítica a toda forma de autoritarismo, características marcantes de Érico Veríssimo, fazem-se presentes ao longo de todo o romance, através de vários personagens. 
Os personagens e a temática de Olhai os lírios do campo tiveram uma continuidade, avançando para o romance Saga. Escrito em 1940, este romance reúne vários personagens do universo literário de Érico Veríssimo e apresenta a culminância da trajetória de Vasco Bruno, personagem de Clarissa, Música ao longe e Um lugar ao sol. Como Eugênio, ele também experimentara vários momentos de crise até se encontrar consigo mesmo e com a paz que sempre procurara.

Esse romance pode ser considerado o prolongamento de Olhai os lírios do campo pela permanência das críticas sociais e, novamente, pela inserção do Sermão da Montanha, com uma interpretação puramente denotativa, desvinculada da verdadeira mensagem que esse texto bíblico traz.

0 processo de autoconhecimento de Eugênio se encerra em Saga. Embora continue assolado pelas marcas de seu passado, ele encontra um sentido para a vida, trabalhando em um hospital para crianças carentes. Com relação à fé, nesse romance ele ainda apresenta dúvidas quanto à existência de Deus, pois não percebe nas pessoas a interação entre fé e obras ou a fé transformada em ações sociais.

Entretanto, algo mudara na vida de Eugênio. Seu olhar, outrora focalizado apenas em si mesmo e sobre seu passado, ganha uma nova direção. Ele consegue encarar o presente e sonhar com o futuro, consegue perceber a fé como esteio para a vida de muitas pessoas, embora não para si mesmo. Sua consciência, outrora tão conflituosa, é apaziguada. Seus dilemas são minimizados no contato com outros personagens, e sua fé, embora tênue e vacilante, encontra no Sermão da Montanha um referencial para a existência humana.

ABSTRACT :

This article intends to show the importance of the religious speech, found in the biblical text "The Sermon of the Mountain", in the building of the characters, in the existing relation between the acceptance of God and the discovery of a sense for living, and the fight against social injustices as a part of the structure of the romantic universe.

KEY WORDS: brazilian novel, modern novel, literature and religion, The Sermon of the Mountain, Érico Verissimo. 
BARTHES, Roland. Introdução à análise estrutural da narratura. In: BARTHES, Roland et al. Análise estrutural da narrativa. 2. ed. Petrópolis: Vozes, 1971. p. 19-60.

BÍBLIA VIDA NOVA. Editor responsável: Russell Shedd. São Paulo: Vida Nova; Brasillia: Sociedade Bíblica do Brasil, 1995.

CHAVES, Flávio Loureiro. Realismo e sociedade. 2. ed. Porto Alegre: Mercado Aberto, 1981. 152 p.(Documentos, 6)

(Org.). O contador de histórias. 40 anos de vida literária de Érico Veríssimo. Porto Alegre: Globo, 1972. p. 71-85: Érico Veríssimo e o mundo das personagens.

GOETHE, Joham Wolfgang von. Os anos de aprendizado de Willhelm Meister. Trad. Nicolino Simone Neto. 2. ed. São Paulo: Ensaio, 1994. 632 p.

GOLDMANN, Lucien. Sociologia do romance. Trad. Álvaro Cabral. 2. ed. Rio de Janeiro: Paz e Terra, 1976. 233 p.

HUXLEY, Aldous. Contraponto. Trad. Érico Veríssimo. São Paulo: Abril Cultural, 1971. 445 p. (0s imortais da literatura universal, 25).

LINHARES, Temístocles. História crítica do romance brasileiro. 1729-1981. Belo Horizonte: Itatiaia; São Paulo: EDUSP, 1987. p. 81-108: As primeiras tentativas; p. 501-536: A alma da raça.

LLOYD-JONES, Martyn. Estudos no Sermão do Monte. 3. ed. São José dos Campos: Editora Fiel, 1992. 606 p.

LUKÁCS, Georg. História e consciência de classe: estudos de dialética marxista. 2. ed. Rio de Janeiro: Elfos Editora; Porto: Publicações Escorpião. 1989. (Biblioteca Ciência e Sociedade, 11). p. 97-231: A reificação e a consciência do proletariado.

POMPERMAYER, Malory J. Érico Veríssimo e o problema de Deus. São Paulo: Edições Loyola, 1968. 124 p.

SIMÕES, João Gaspar. Crítica I. A prosa e o romance contemporâneos. Porto: Livraria Latina Editora, 1942. p. 380-392: Érico Veríssimo. 01hai os lírios do campo. STOTT, John. A mensagem do Sermão do Monte. 2. reimp. [s.1.]: ABU Editora, 1993. 235 p.

VERÍSSIMO, Érico. Olhai os lírios do campo. 32. ed. Porto Alegre: Globo, 1976. 290 p. - Saga. 2. ed. Porto Alegre: Globo, 1969. 345 p. 